\title{
Comparison of Size-Exclusion Chromatography and Flow Field-Flow Fractionation for Separation of Whey Proteins
}

\author{
Da Young Kang, Jae Mi Moon, and Seungho Lee* \\ Department of Chemistry, Hannam University, Daejeon 305-811, Korea. *E-mail: slee@hannam.kr \\ Received January 14, 2011, Accepted February 26, 2011
}

\begin{abstract}
Whey protein (WP) is a mixture of proteins, and is of high nutritional values. WP has become an important source of functional ingredients in various health-promoting foods. In this study, size-exclusion chromatography (SEC) and asymmetrical flow field-flow fractionation (AsFlFFF) were used for separation and analysis of whey proteins. It was found that a lab-prepared WP from raw milk is mostly of $\beta$-lactoglobulin with small amount of higher molecular weight components, while a commercial whey protein isolate (WPI) powder contains relatively larger amount of components other than $\beta$-lactoglobulin, including IgG and protein aggregates. Results suggest that AsFlFFF provides higher resolution for the major whey proteins than SEC in their normal operation conditions. AsFlFFF could differentiate the BSA and Albumin, despite a small difference in their molecular weights, and also was able to separate much smaller amount of aggregates from monomers. It is noted that SEC was able to show the presence of low molecular weight components other than the major whey proteins in the WP samples, which AsFIFFF could not show, probably due to the partial loss of those low molecular weight species through the membrane.
\end{abstract}

Key Words : Whey proteins, Whey protein isolate (WPI), Separation, Asymmetrical flow field-flow fractionation (AsFlFFF), Size-exclusion chromatography (SEC)

\section{Introduction}

Whey protein (WP) is a mixture of proteins, having the four major components such as $\beta$-lactoglobulin $(\beta-\mathrm{Lg}), \alpha-$ lactalbumin ( $\alpha$-Lac), bovine serum albumin (BSA), and immunoglobulin (IgG). ${ }^{1,2}$ Minor components include lactoferrin, lactoperoxidase, enzymes, and proteose-peptone (PP) fractions. ${ }^{3}$ The composition of WP varies depending upon the whey resource and the procedure by which the WP was processed.

WP is of high nutritional value, and has become an important source of functional ingredients in various healthpromoting foods. ${ }^{4} \mathrm{WP}$ is also widely used as an emulsifier and stabilizer in the food industry. It has been reported that WP may possess anti-inflammatory or anti-cancer properties, ${ }^{5,6}$ and has been tested as a supplementary treatment for human diseases. ${ }^{7}$

Various methods such as ultrafiltration, high pressure ${ }^{8}$ or heat-treatment are used to improve the functional properties of WP, which may cause changes in physico-chemical properties as well as the functional properties of WP proteins. A high pressure-treated whey proteins showed better stabilizing properties by an increase of their surface hydrophobicity, thus enhancing foaming ability and stability. ${ }^{8} \mathrm{WP}$ proteins are heat-sensitive, and have a tendency to form a gel or aggregates after heat-induced denaturation due to conformational changes and subsequent aggregation., ${ }^{4,10}$ The heat-induced denaturation and aggregation are also affected by $\mathrm{pH}$ and ionic environment of the medium. ${ }^{11,12}$ For valueadded industrial applications of WP, the composition and the changes in both the physico-chemical and functional properties need to be accurately analyzed. It is noted that, even for the same WP sample, there may be wide variation in the protein concentrations measured by different analytical methods. ${ }^{1}$

Because WP is a mixture of proteins, accurate analysis of WP requires separation of the WP proteins. Various separation methods have been suggested to separate and analyze the whey proteins. ${ }^{3}$ They include gel electrophoresis. ${ }^{1,8,13-15}$ capillary zone electrophoresis, ${ }^{1,16-18}$ and various forms of high performance liquid chromatography (HPLC). ${ }^{15,19-25}$ The HPLC methods include reversed-phase, ${ }^{15,19-22}$ ion exchange, ${ }^{23-26}$ and size-exclusion chromatography (SEC). ${ }^{8,11,12,18,26,27}$ No single method is applicable for separation of all whey proteins and the choice of a method is usually based on one or two components of interest. ${ }^{15}$ In ion-exchange HPLC, usually a large amount of mobile phase is used with various concentrations of salts or at different $\mathrm{pH}$ to wash out the target proteins, and in reversed-phase HPLC, some organic solvents or an acidic mobile phase are often used, all of which could cause denaturation of whey proteins.

Compared to other forms of HPLC, SEC is relatively gentle to protein molecules and has been widely used in separation of proteins. ${ }^{27,28}$ SEC is a standard method in various industries for determination of molecular weight distribution (MWD) of polymers because it provides separation based on the molecular size. However SEC, like other forms of HPLC using packed columns, can only be applied to soluble components. As mentioned earlier, heat-induced denaturation of whey proteins and associated formation of insoluble protein aggregates can occur, thus leading to loss of proteins measurable by SEC or reversed-phase HPLC. It has been 
reported that the protein concentrations measured by reversedphase HPLC were lower than those found by gel electrophoresis due to the removal of insolubles or large aggregates during analysis. ${ }^{15}$ Application of SEC is also limited by the pore size of the stationary gels. The aggregates or large molecules are often too large to be effectively separated on typical SEC columns. Also an adsorption of the sample may occur onto the stationary gels of the SEC columns due to solute-gel interactions, which disturbs the size-based separation. Electrostatic repulsion between the sample and the stationary gels may also occur. ${ }^{29}$

Flow field-flow fractionation (FlFFF) provides separation of particles or macromolecules based on the differences in the diffusion coefficients, ${ }^{30}$ and may become an alternative to SEC for separation of whey proteins. The applicability of FIFFF has been shown for analysis of proteins, ${ }^{31}$ where BSA was used to study the effect of carrier composition (ionic strength and $\mathrm{pH}$ ) on the retention FlFFF. It was reported that the retention of BSA in FlFFF increases with ionic strength of the carder liquid. Also reported was the hydrodynamic diameters obtained from FlFFF retention data agrees well with theoretical values. It has also been reported that FIFFF is useful for characterization of various samples such as polymers ${ }^{32,33}$ polysaccharides ${ }^{34}$ ribosome,${ }^{35}$ tRNA levels in bacterial cells, ${ }^{36}$ gelatin nanoparticles drug carrier systems, ${ }^{37}$ and pullulan, ${ }^{38}$ etc.

The openness of the FlFFF channel (unpacked) may provide several potential advantages over SEC for WP separation and analysis. An open channel has much less surface area than packed columns, reducing opportunity for adsorption. And the flow through open channels is less tortuous than in packed columns, minimizing shear-induced molecular degradation. It has been reported that FIFFF provides better resolution than SEC for the species having molecular weight higher than about $10,000 \mathrm{Da},{ }^{29}$ although $\mathrm{SEC}$ is better for lower molecular weight region.

In this study, two WP samples (the WP isolated from raw milk in the laboratory and a commercial whey protein isolate (WPI) powder) were analyzed using asymmetrical FIFFF (AsFlFFF) and SEC. The capabilities of the two separation techniques were compared.

\section{Theory}

In AsFlFFF, the retention time ( $\left.t_{\mathrm{r}}\right)$ of a sample is determined by its diffusion coefficient $(D)$ and is given by ${ }^{39}$

$$
t_{r}=\frac{t^{\mathrm{o}} F_{c} w^{2}}{6 D V^{0}}
$$

, where $t^{0}$ is the void time, $w$ the channel thickness, $V^{0}$ the void volume of the channel, and $F_{c}$ the cross-flow rate. According to eqn. (1), $D$ can be directly determined by measuring $t_{\mathrm{r}}$, from which the hydrodynamic diameter $\left(d_{\mathrm{H}}\right)$ can be measured by the Stokes-Einstein equation:

$$
d_{\mathrm{H}}=\frac{k T}{3 \pi \eta D}
$$

, where $k$ is the Boltzmann constant, $T$ the absolute temperature, and $\eta$ the viscosity of the carrier liquid. It is noted that eqn. (1) is a simplified expression of $t_{\mathrm{r}}$ that is applicable only for spherical particles having relatively high retention. Application of eqn. (1) is also limited to the cases where there are no physical interactions such as the interactions among the sample molecules or the interactions between the sample and the channel wall (membrane).

As shown in eqn. (1), the ratio of the flow rates, $F_{\mathrm{c}} / F_{\text {out }}$, is an important parameter that determines the degree of retention of a sample. For the same sample, $t_{\mathrm{r}}$ increases with $F_{\mathrm{c}}$

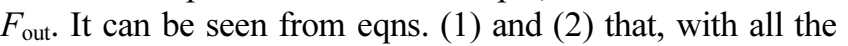
experimental parameters fixed, $d_{\mathrm{H}}$ is directly proportional to $t_{\mathrm{r}}$, thus allowing a size-based separation.

\section{Experimental Section}

Materials. Raw milk was purchased from Pasteur Milk (Hweng-Seong, Korea). A commercial whey protein isolate (WPI) powder was obtained from Hansol Tech (Gim-Po, Korea). WPI powder is whey protein obtained by removing fat and lactose, and is high in protein content (usually higher than $90 \%$ ). Five protein standards were purchased from Sigma-Aldrich Co. (St. Louis, MO, USA), and are listed in Table 1.

Isolation of Whey Proteins from Raw Milk. Whey proteins were isolated directly from a raw milk by a simple and gentle procedure similar to that described elsewhere. ${ }^{18}$ Raw milk was refrigerated at $-18{ }^{\circ} \mathrm{C}$ overnight. The fat solidified at the top was removed. The remainder was thawed by storing the solution at $4{ }^{\circ} \mathrm{C}$ for about $1 \mathrm{hr}$, and then centrifuged at $12,000 \mathrm{rpm}$ for $30 \mathrm{~min}$ to remove other residues which are precipitated by centrifugation. After the centrifugation, the pale-greenish transparent solution was taken, and then was treated with $0.1 \mathrm{M} \mathrm{HCl}$ solution to adjust the solution $\mathrm{pH}$ to 4.6 , which resulted in precipitation of casein. Finally the solution was filtered through $0.45 \mu \mathrm{m}$ disposable filter (Whatman, Maidstone, UK) before the injection into the SEC columns or into the AsFIFFF channel.

Preparation of Solution of WPI Powder. A 3\% (w/w) stock solution was prepared by adding WPI powder to deionized water and stirring gently for $2 \mathrm{~h}$ at room temperature. The solution was then stored overnight at 4 to allow complete hydration. Some insolubles were precipitated. The solution was taken, and $\mathrm{pH}$ was adjusted to 6.0 using $1 \mathrm{M}$

Table 1. Protein standards used in this study

\begin{tabular}{lc}
\hline \multicolumn{1}{c}{ Protein } & $\begin{array}{c}\text { Nominal MW } \\
(\mathrm{Da})\end{array}$ \\
\hline$\beta$-lactoglobulin ( $\beta$-Lg, from bovine milk, appr. 80\%) & $1.8 \times 10^{4}$ \\
Albumin (bovine albumin, min 98\%) & $6.6 \times 10^{4}$ \\
Bovine Serum Albumin (BSA, min 99\%) & $6.7 \times 10^{4}$ \\
Immunoglobulin (IgG, from human serum, reagent & $1.50 \times 10^{5}$ \\
$\quad$ grade, min 95\%) & \\
Ferritin (from horse spleen, 76 mg/mL) & $4.40 \times 10^{5}$ \\
\hline
\end{tabular}


$\mathrm{HCl}^{8}{ }^{8}$ Finally the solution was filtered through a $0.45 \mu \mathrm{m}$ disposable filter (Whatman, Maidstone, UK) before the injection into the SEC columns or into the AsFIFFF channel.

Asymmetrical Flow Field Flow Fractionation (AsFIFFF). The AsFlFFF system used in this study was the Eclipse AF4 (Wyatt Tech., Europe GmbH, Dernbach, Germany) assembled with a 350- $\mu \mathrm{m}$-thick Mylar spacer and a regenerated cellulose membrane (Millipore, Bedford, MA, USA) having the cutoff-molecular weight of 10,000 Da. The channel geometry was trapezoidal with the tip-to-tip length of $26.5 \mathrm{~cm}$ and the breadth at the inlet and the outlet of 1.7 and $0.39 \mathrm{~cm}$, respectively. To measure the actual channel thickness, ferritin was injected with the carrier liquid of water containing $0.02 \% \mathrm{NaN}_{3}$. The channel thickness determined from the measured retention time of ferritin was $289 \mu \mathrm{m}$. A HPLC pump was used to deliver the carrier liquid which was water containing $0.05 \mathrm{M}$ Tris- $\mathrm{HCl}\left(\mathrm{pH} 7.2\right.$ ) and $0.02 \% \mathrm{NaN}_{3}$ to the channel. The channel and the cross-flow rate were measured using liquid flow meters (Optiflow 1000, Agilent Technologies, Palo Alto, CA, USA). Eluted samples were monitored using a refractive index (RI) detector (Shodex RI-71, Showa Denko, Tokyo, Japan). The sample solution was injected using a 20 $\mu \mathrm{L}$ loop injector (Rheodyne 7125, Cotati, CA, USA). A syringe pump (KD Scientific Model 100, Holliston, MA, USA) was used at the flow rate of $0.2 \mathrm{~mL} / \mathrm{min}$ for $60 \mathrm{sec}$ to load the sample into the channel. After the injection, the sample was focused and relaxed for another $50 \mathrm{sec}$ before the elution began at the channel flow rate of $2 \mathrm{~mL} / \mathrm{min}$.

Size-exclusion Chromatography (SEC). A series of three Shodex OHpak columns (SB-803HQ, SB-804HQ, SB$805 \mathrm{HQ})$ was used to separate the WP samples. The carrier liquid was water containing $0.05 \mathrm{M}$ Tris- $\mathrm{HCl}(\mathrm{pH} 7.2)$ and $0.02 \% \mathrm{NaN}_{3}$. The flow rate was set at $0.5 \mathrm{~mL} / \mathrm{min}$ for all SEC analysis in this paper. Proteins were detected by a RI detector (Shodex RI-71, Showa Denko, Tokyo, Japan). Sample solution was injected using a $50 \mu \mathrm{L}$ loop injector (Rheodyne 7125, Cotati, CA, USA).

\section{Results and Discussion}

Separation of WP by AsFIFFF. Figure 1 shows AsFIFFF fractograms obtained at various cross-flow rates $\left(F_{\mathrm{c}}\right)$ for the WP isolated from raw milk (Fig. 1(a)) and the WPI powder (Fig. 1(b)). All the experimental conditions were the same including the channel-flow rate $\left(F_{\text {out }}\right)$ which was $0.2 \mathrm{~mL} /$ min. The signals shown in Figure 1 at the beginning of the fractograms (before about $2 \mathrm{~min}$ ) are combinations of the pressure pulses and the void peaks. The void time $\left(t^{\circ}\right)$ was $1.04,0.90,0.84$, and $0.77 \mathrm{~min}$ at $F_{\mathrm{c}}$ of $2.4,3.0,3.3$, and 3.8 $\mathrm{mL} / \mathrm{min}$, respectively.

In Figure 1(a), the AsFlFFF fractograms show a major peak eluting first, followed by a few unresolved minor ones. The retention of the sample (and thus the resolution) gradually increases as $F_{\mathrm{c}}$ increases from 2.4 up to $3.3 \mathrm{~mL} /$ min, as expected from FlFFF theory. Generally in FlFFF, as $F_{\mathrm{c}}$ increases, sample components are pushed closer to the accumulation wall, which results in longer retention time.

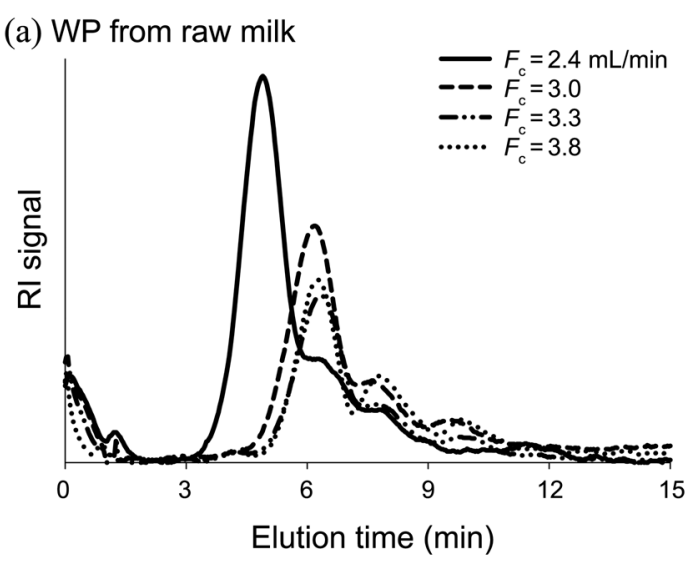

(b) WPI powder

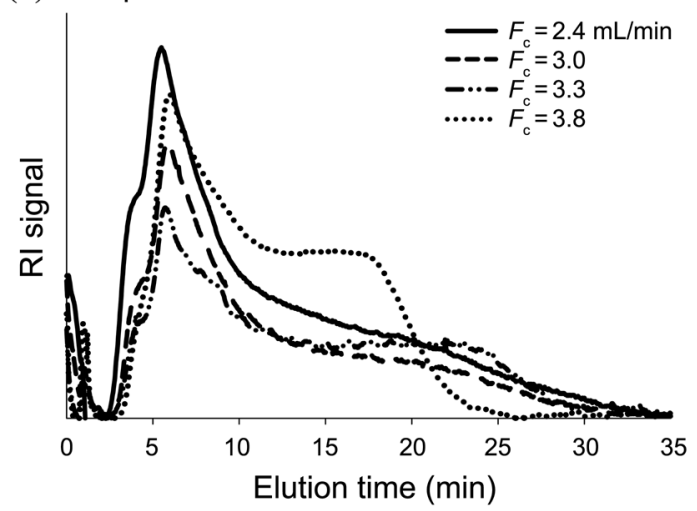

Figure 1. AsFIFFF fractograms of WP isolated from raw milk (a) and WPI powder (b) obtained at various cross-flow rates. $F_{\text {out }}$ was fixed at $0.2 \mathrm{~mL} / \mathrm{min}$.

When $F_{\mathrm{c}}$ was further increased from 3.3 up to $3.8 \mathrm{~mL} / \mathrm{min}$, no significant changes were found. In the range of $F_{\mathrm{c}}$ employed, the elution of WP isolated from raw milk was completed within about $15 \mathrm{~min}$.

In Figure 1(b), the elution profiles of the WPI powder are rather continuous and much broader than those in Figure 1(a). Longer analysis time of about $35 \mathrm{~min}$, instead of 15 min, was required, indicating the WPI powder contains higher molecular weight species than the WP isolated from raw milk or the aggregates that were produced during manufacture of WPI powder. Also the change in retention with $F_{\mathrm{c}}$ is less obvious than in Figure 1(a). It is noted in Figure 1(b) that, when $F_{\mathrm{c}}$ was increased from 3.0 to 3.3 and to $3.8 \mathrm{~mL} /$ $\mathrm{min}$, the latter part of the fractogram (higher retention) tends to elute earlier. It may be partly due to repulsion among the sample molecules or by the steric inversion by the large sized aggregates. ${ }^{40}$ In FIFFF, the sample layer formed on the accumulation wall becomes thinner, and the sample components come closer to each other, increasing the probability of repulsion among the sample molecules. $F_{\mathrm{c}}$ of $3.0 \mathrm{~mL} / \mathrm{min}$ was chosen in all AsFIFFF analysis of WP samples in this paper.

Figure 2 shows AsFlFFF fractograms of whey protein standards obtained at $F_{\text {out }}$ and $F_{\mathrm{c}}$ of 0.20 and $3.0 \mathrm{~mL} / \mathrm{min}$, respectively. All other experimental conditions were the same as those in Figure 1. As expected, the retention time of the 


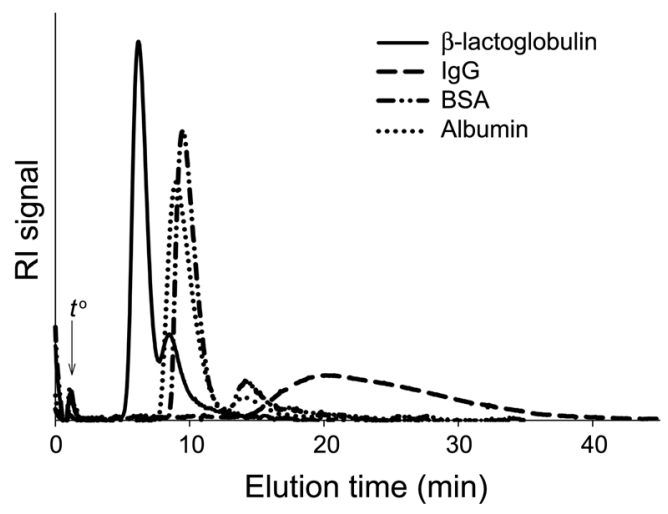

Figure 2. AsFlFFF fractograms of protein standards obtained at $F_{\mathrm{c}}=3.0, F_{\text {out }}=0.2 \mathrm{~mL} / \mathrm{min}$. All other experimental conditions were the same as those in Figure 1.

protein standard increases as the nominal molecular weight increases, showing the capability of AsFlFFF for molecular weight-based separation of proteins. As the molecular weight increases, the diffusion coefficient, $D$, decreases, and thus the retention time, $t_{\mathrm{r}}$, increases as shown in eqn. (1). The fractograms of $\beta$-Lg, BSA and Albumin show small peak eluting right after the main population, which are probably of the aggregates. The fractogram of $\mathrm{IgG}$ is much broader than those of other proteins. It is noted that the elution time of Albumin and BSA is 8.9 and 9.6 min, respectively, suggesting AsFlFFF can differentiate them, despite a small difference in their molecular weights (the nominal molecular weight of Albumin and BSA is $6.6 \times 10^{4}$ and $6.7 \times 10^{4}$, respectively).

Table 2 shows the diffusion coefficients $(D)$ of the proteins shown in Figure 2 that were determined using eqn. (1) from their retention times $\left(t_{\mathrm{r}}\right)$. The retention times were measured at the highest points of the RI signals. Table 2 also shows the hydrodynamic diameters $\left(d_{\mathrm{H}}\right)$ of the proteins determined using eqn. (2) from the measured $D$ values ( $D_{\text {measured }}$ ). It can be seen that the $D_{\text {measured }}$ values agree well with those from other literatures. ${ }^{41-44}$ Figure 3 shows the log-log plot of the diffusion coefficients measured for the proteins (open circles) vs. their nominal molecular weights $(M)$. The dashed line is the result of the first order linear regression. The linear function and the correlation coefficients are also shown in Figure 3. Figure 3 may be used to determine the molecular weights of unknown proteins from the diffusion coefficients obtained from its AsFIFFF retention time.

Figure 4 shows AsFIFFF fractograms of the protein

Table 2. Diffusion coefficients of proteins measured by AsFlFFF

\begin{tabular}{|c|c|c|c|}
\hline Proteins & $\begin{array}{c}D_{\text {reference }}{ }^{a} \\
\left(\mathrm{~cm}^{2} / \mathrm{s}\right)\end{array}$ & $\begin{array}{c}D_{\text {measured }}^{b} \\
\left(\mathrm{~cm}^{2} / \mathrm{s}\right)\end{array}$ & $\underset{(\mathrm{nm})}{d_{\mathrm{H}, \text { measured }}{ }^{c}}$ \\
\hline$\beta$-lactoglobulin & $9.7 \times 10^{-7}$ & $1.1 \times 10^{-6}$ & 4.7 \\
\hline Albumin & $7.8 \times 10^{-7}$ & $7.1 \times 10^{-7}$ & 6.9 \\
\hline BSA & $6.7 \times 10^{-7}$ & $6.8 \times 10^{-7}$ & 7.2 \\
\hline Immunoglobulin & $3.8 \times 10^{-7}$ & $3.4 \times 10^{-7}$ & 14.5 \\
\hline
\end{tabular}

${ }^{a}$ literature values [41-44]. ${ }^{b}$ measured using Eq. (1) from $t_{\mathrm{r}}$ measured at the peak maximum. ${ }^{c}$ measured using Eq. (2) from $D_{\text {measured. }}$

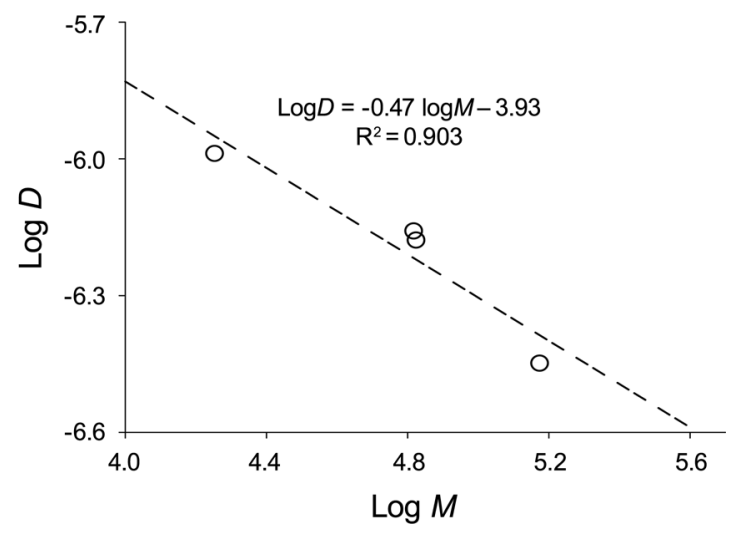

Figure 3. Diffusion coefficients $(D)$ determined for proteins shown in Figure 2 plotted against their nominal molecular weights $(M)$.

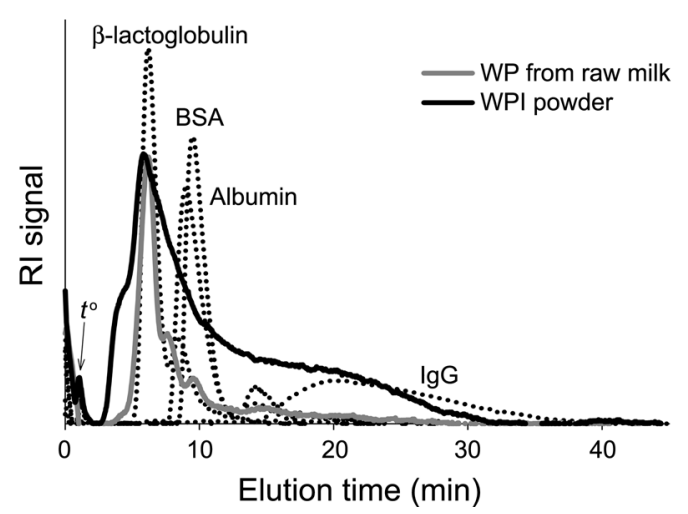

Figure 4. AsFIFFF fractograms of proteins standards overlaid with those of two WP samples. Experimental conditions are the same as those in Figure 1.

standards (shown in Figure 2) overlaid with those of two WP samples. All the fractograms of the protein standards are in dotted lines, while those of the WP samples are in solid lines (grey line for the WP from raw milk and dark line for the WPI powder). It can be seen that the leading major population of WP from raw milk is of $\beta$-Lg. And the partially resolved minor components eluting after $\beta-\mathrm{Lg}$ are other higher molecular weight whey proteins and their aggregates. Figure 3 also shows $\beta$-Lg is a major component of the WPI powder.

Compared to the WP obtained from raw milk, the WPI powder contains relatively higher amount of other components than $\beta-\mathrm{Lg}$, including IgG. This result may suggest the efficiency in isolating whey proteins from raw milk was not high. The earlier eluting shoulder to the major peak $(\beta-\mathrm{Lg})$ is predicted to be that of the $\alpha$-lactalbumin, whose molecular weight is slightly lower $\left(1.4 \times 10^{4} \mathrm{Da}\right)$ than that of $\beta$-Lg $\left(1.8 \times 10^{4} \mathrm{Da}\right)$.

Separation of WP by Size-exclusion Chromatography (SEC). Figure 5 shows SEC chromatograms of the protein standards obtained at the flow rate of $0.5 \mathrm{~mL} / \mathrm{min}$. The column temperature was set to be $30{ }^{\circ} \mathrm{C}$. This time, the elution order is reversed from that obtained from AsFIFFF, where the elution time of the protein standards decreases as the nominal molecular weight increases. In Figure 5, the 


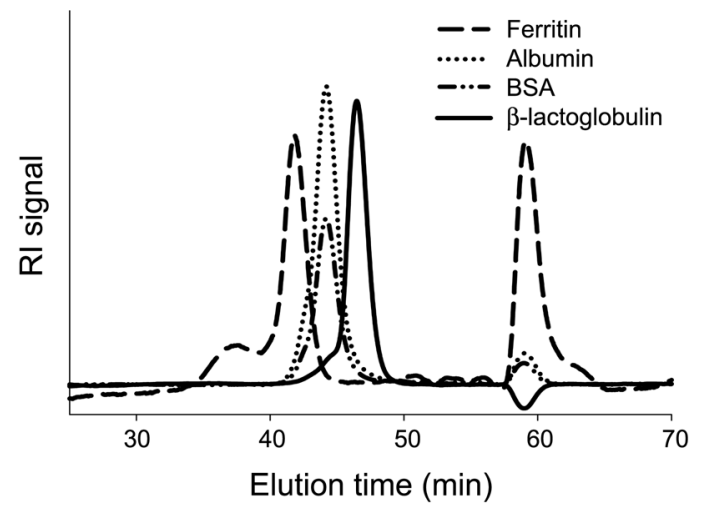

Figure 5. SEC chromatograms of protein standards obtained at the flow rate of $0.5 \mathrm{~mL} / \mathrm{min}$ and at the column temperature of $30{ }^{\circ} \mathrm{C}$.

elution times of Albumin and BSA are almost same at around 44.2 min. Thus, unlike AsFIFFF, SEC could not differentiate albumin and BSA due to the closeness in their molecular weights. Also the resolution between monomers and aggregates are poorer than in AsFlFFF (Fig. 2) for $\beta$-Lg, BSA and Albumin. In Figure 5, the chromatogram of IgG is not shown because it was difficult to obtain a reasonable elution profile for $\operatorname{IgG}$ at the same experimental conditions, which seems to need more investigation.

Figure 6 shows SEC chromatograms of WP samples overlaid with those of the protein standards. Again, all the chromatograms of the protein standards are in dotted lines, while those of the WP samples are in solid lines (grey line for the WP obtained from raw milk and dark line for the WPI powder). The SEC results of the two WP samples are generally in the same trends with the AsFIFFF results (Fig. 4). However, the resolutions for the major whey proteins are lower in SEC than in AsFIFFF. Also the total analysis time for SEC analysis is longer than that for AsFIFFF.

The SEC results shown in Figure 6 suggest a large amount of low molecular weight components are present in both WP samples, which are most probably the low molecular weight species such as the proteose-peptone (PP) fractions, orotic acid and hippuric acid. ${ }^{1}$ These low molecular weight species were not found in AsFlFFF fractograms. It is likely that, in

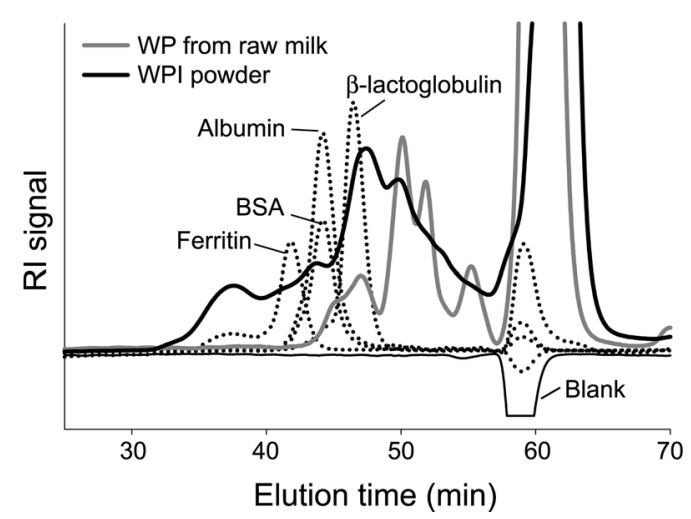

Figure 6. SEC chromatograms of WP samples overlaid with those of protein standards. Experimental conditions are the same as those in Figure 4.
AsFlFFF, those low molecular weight species may have passed through the membrane, which has the cutoff-molecular weight of 10,000 Da.

\section{Conclusions}

Capabilities of SEC and AsFlFFF were compared for separation of whey proteins in their normal operating conditions. It is clear that the two techniques are different in the separation mechanism, and one can do something better that the other, and vice versa. SEC can provide better resolution than AsFlFFF for lower molecular weight components of whey protein. For the major whey protein components, however, results suggest AsFIFFF could provides higher resolution than SEC. Unlike SEC, AsFIFFF could differentiate the BSA and Albumin, despite a small difference in their molecular weights. AsFIFFF was also able to separate protein aggregates present in much lower concentration from the monomers.

The performance of AsFlFFF could be further improved by adopting the field- or flow programming. ${ }^{45}$ Testing of various types of membranes may be needed. The onlinecoupling of the multi angle light scattering (MALS) will also improve AsFIFFF by allowing absolute determination of the molecular weight, sizes, and the molecular conformations of the proteins. ${ }^{46-49}$ With further improvements, and fine-tuning, AsFlFFF is expected to have wide application in the routine analysis of whey proteins.

Acknowledgments. Authors acknowledge support from Hannam University. This research was also supported by Basic Science Research Program through the National Research Foundation of Korea (NRF) funded by the Ministry of Education, Science and Technology (2010-0003133).

\section{References}

1. Kinghorn, N. M.; Norris, C. S.; Paterson, G. R.; Otter, D. E. J. Chromatogr. A 1995, 700, 111.

2. Eigel, W. N.; Butler, J. E.; Ernstrom, C. A.; Farrell, H. M., Jr.; Harwalkar, V. R.; Jenness, R.; Whitney, R. M. J. Dairy Sci. 1984, $67,1599$.

3. Strange, E. D.; Malin, E. L.; Van Hekken, D. L.; Basch, J. J. J. Chromatogr. 1992, 624, 81.

4. McIntosh, G. H.; Royle, P. J.; Le Leu, R. K.; Regester, G. O.; Johnson, M. A.; Grinsted, R. L.; Kenward, R. S.; Smithers, G. W. Int. Dairy J. 1998, 8, 425.

5. Xiao, R.; Carter, J. A.; Linz, A. L.; Ferguson, M.; Badger, T. M.; Simmen, F. A. J. Nutr. Biochem. 2006, 17, 626.

6. Hakkak, R.; Korourian, S.; Ronis, M. J. J.; Johnston, J. M.; Badger, T. M. Cancer Epidemiology Biomarkers and Prevention 2001, 10, 555.

7. Krissansen, G. W. J. Am. Coll. Nutr. 2007, 26.

8. Bouaouina, H.; Desrumaux, A.; Loisel, C.; Legrand, J. Int. Dairy J. 2006, 16, 275.

9. De La Fuente, M. A.; Hemar, Y.; Singh, H. Food Chem. 2004, 86, 1.

10. Hoffmann, M. A. M.; Sala, G.; Olieman, C.; De Kruif, K. G. J. Agric. Food. Chem. 1997, 45, 2949.

11. de Wit, J. N.; Kessel, T. V. Food Hydrocolloids 1996, 10, 143.

12. Beaulieu, M.; Corredig, M.; Turgeon, S. L.; Wicker, L.; Doublier, 
J.-L. Food Hydrocolloids 2005, 19, 803.

13. Ng-Kwai-Hang, K. F.; Kroeker, E. M. J. Dairy Sci. 1984, 67, 3052 .

14. Basch, J. J.; Douglas, F. W., Jr.; Procino, L. G.; Holsinger, V. H.; Farrell, H. M., Jr. J. Dairy Sci. 1985, 68, 23.

15. Elgar, D. F.; Norris, C. S.; Ayers, J. S.; Pritchard, M.; Otter, D. E.; Palmano, K. P. J. Chromatogr. A 2000, 878, 183.

16. De Jong, N.; Visser, S.; Olieman, C. J. Chromatogr. 1993, 652, 207.

17. Otte, J. A. H. J.; Kristiansen, K. R.; Zakora, M.; Qvist, K. B. Neth. Milk J. 1994, 48, 81.

18. Liang, M.; Chen, V. Y. T.; Chen, H.-L.; Chen, W. Talanta 2006, 69, 1269.

19. Saito, T.; Yamaji, A.; Itoh, T. J. Dairy Sci. 1991, 74, 2831.

20. Leonil, J.; Molle, D.; Fauquant, J.; Maubois, J. L.; Pearce, R. J.; Bouhallab, S. J. Dairy Sci. 1997, 80, 2270.

21. Torre, M.; Cohen, M. E.; Corzo, N.; Rodríguez, M. A.; DiezMasa, J. C. J. Chromatogr. A 1996, 729, 99.

22. García, M. C.; Marina, M. L.; Torre, M. J. Chromatogr. A 1998 , 822,225

23. Manji, B.; Hill, A.; Kakuda, Y.; Irvine, D. M. J. Dairy Sci. 1985, $68,3176$.

24. Vogt, S.; Freitag, R. J. Chromatogr. A 1997, 760, 125.

25. Gerberding, S. J.; Byers, C. H. J. Chromatogr. A 1998, 808, 141.

26. El-Sayed, M. M. H.; Chase, H. A. Biotechnol. Progr. 2010, 26, 192.

27. Al-Mashikhi, S. A.; Nakai, S. J. Dairy Sci. 1987, 70, 2486.

28. Yoshida, S. J. Dairy Sci. 1990, 73, 2292.

29. Pelekani, C.; Newcombe, G.; Snoeyink, V. L.; Hepplewhite, C.; Assemi, S.; Beckett, R. Environ. Sci. Technol. 1999, 33, 2807.

30. Yohannes, G.; Sneck, M.; Varjo, S. J. O.; Jussila, M.; Wiedmer, S. K.; Kovanen, P. T.; Öörni, K.; Riekkola, M. L. Anal. Biochem.
2006, 354, 255 .

31. Song, J. H.; Kim, W. S.; Park, Y. H.; Yu, E. K.; Lee, D. W. Bull. Korean Chem. Soc. 1999, 20, 1159.

32. Wittgren, B.; Wahlund, K. G.; Dérand, H.; Wesslén, B. Macromolecules 1996, 29, 268.

33. Benincasa, M. A.; Giddings, J. C. Anal. Chem. 1992, 64, 790.

34. Wittgren, B.; Wahlund, K. G. J. Chromatogr. A 1997, 760, 205.

35. Moon, M. H.; Park, I.; Kim, Y. J. Chromatogr. A 1998, 813, 91.

36. Lee, H.; Williams, S. K. R.; Wahl, K. L.; Valentine, N. B. Anal. Chem. 2003, 75, 2746.

37. Mao, S.; Augsten, C.; Mäder, K.; Kissel, T. J. Pharm. Biomed. Anal. 2007, 45, 736.

38. Kirkland, J. J.; Dilks, C. H., Jr.; Rementer, S. W. Anal. Chem. 1992, 64, 1295.

39. Wahlund, K. G.; Giddings, J. C. Anal. Chem. 1987, 59, 1332.

40. Lee, S.; Calvin Giddings, J. Anal. Chem. 1988, 60, 2328.

41. Abremski, K.; Hoess, R. J. Biol. Chem. 1984, 259, 1509.

42. Jøssang, T.; Feder, J.; Rosenqvist, E. J. Protein Chem. 1988, 7, 165.

43. Gilbert, L. M.; Gilbert, G. A. Nature 1961, 192, 1181.

44. Shen, J. J. S.; Probstein, R. F. Ind. Eng. Chem. Fundam. 1977, 16, 459.

45. Kim, W. J.; Chul, H. E.; Lim, S. T.; Han, J. H.; You, S. G.; Lee, S. Bull. Korean Chem. Soc. 2007, 28, 2489.

46. Lee, S.; Kim, S. T.; Pant, B. R.; Kwen, H. D.; Song, H. H.; Lee, S. K.; Nehete, S. V. J. Chromatogr. A 2010, 1217, 4623.

47. Modig, G.; Nilsson, L.; Bergenståhl, B.; Wahlund, K. G. Food Hydrocolloids 2006, 20, 1087.

48. Modig, G.; Nilsson, P. O.; Wahlund, K. G. Starch/Staerke 2006, 58,55 .

49. Moon, M. H.; Shin, D. Y.; Lee, N.; Hwang, E.; Cho, I. H. J. Chromatogr., B: Anal. Technol. Biomed. Life Sci. 2008, 864, 15. 